\title{
New Trends in The Representation of Women in Contemporary Media Culture: A Critical Analysis of Three Women Empowering Advertising Campaigns*
}

\author{
Nermin ALKAN
}

PhD candidate university of sussex, school of media, film and music n.alkan@sussex.ac.uk

\begin{abstract}
Unlike previous scholarly research which has examined women representation in the media by highlighting the point that women have long been depicted as passive and dependent on men thereby reproducing traditional gender roles, this research aimed to discover the newly emerging trends in the women's media representation, in which over the last decade women have been represented in empowered and liberalized manner. Through social semiotic and critical discourse analysis of ALWAYS: Like a Girl (2014), CoverGirl: Girls Can (2014) and Gillette Venus: Use Your And (2015) advertising campaigns' representational practices about women in the example of campaigns' video commercials, this research concluded that while these campaigns' visual texts construct the meaning of empowered women as independent and powerful by way of producing the myths of contemporary women as physically active, multidimensional, authoritative, darer, courageous, funny, successoriented and unstoppable, these representations strive to promote women's empowerment rhetoric to reach advanced consumerism targets of commercial companies through encouraging women to consume recommended brands as a sign of their independence and feminine power.
\end{abstract}

keywords: neoliberalism, (popular) postfeminism, gender relations, visual representation, women empowering advertising campaigns

* A wider version of this research was submitted to the University of Leeds School of Media and Communication in accordance with the requirements for the MA degree. 


\section{Résumé}

\section{Nouvelles tendances dans la représentation médiatique des femmes au sein de la culture contemporaine: Une analyse critique des campagnes de publicité pour l'autonomisation des femmes}

Contrairement aux recherches académiques précédentes qui ont examiné la représentation des femmes dans les médias en mettant accent sur le fait que les femmes ont longtemps été décrites comme passives et dépendantes des hommes, reproduisant ainsi les rôles traditionnels des genres, cette étude a visé à découvrir les tendances émergentes dans la représentation médiatiques des femmes dans le cadre desquelles, au cours des dix dernières années, les femmes sont représentées dans une manière autonomisée et libéralisée. Grâce à l'analyse du discours socio-sémiotique et critique des pratiques représentationnelles sur les femmes dans les exemples des vidéos publicitaires des campagnes pour ALWAYS: Like a Girl (2014), CoverGirl: Girls Can (2014) et Gillette Venus: Use Your And (2015), cette recherche a conclu que quand ces textes visuels construisent le sens de la femme émancipée comme indépendante et puissante en produisant des mythes de la femme contemporaine physiquement active, multidimensionnelle, autoritaire, osée, courageuse, drôle, ambitieuse et imparable, ces représentations visent à promouvoir la rhétorique de l'autonomisation des femmes pour atteindre les objectifs de consumérisme avancé des sociétés commerciales en encourageant les femmes à consommer des marques recommandées comme un signe de leur indépendance et de leur pouvoir féminin.

mots-clés: néolibéralisme, (populaire) post-féminisme, relations entre les genres, représentation visuelle, les campagnes de publicité pour l'autonomisation des femmes 
Öz

\section{Çağdaş Medya Kültüründe Kadının Medyadaki Temsilinde Yeni Eğilimler: Kadın Güçlendirme Reklam Kampanyalarının Eleştirel Analizi}

Kadınların medyadaki temsilini kadının medyada edilgen ve erkeğe bağımlı olarak tasvir edildiğinin ve böylece geleneksel cinsiyet rollerinin yeniden üretildiğinin altını çizerek incelemiş olan akademik araştırmaların aksine, bu çalışma kadının medya temsilinde yeni ortaya çıkan ve son on yıldır kadınları güçlendirilmiş ve liberalize edilmiş şekilde sunan eğilimleri anlamayı amaçlamıştır. ALWAYS: Like a Girl (2014), CoverGirl: Girls Can (2014) ve Gillette Venus: Use Your And (2015) reklam kampanyalarının kadına ilişkin temsil pratiklerinin kampanyaların video reklamları örneğinde sosyal göstergebilimsel ve eleştirel söylem analizi yoluyla incelenmesi sonucu araştırmanın vardığı sonuca göre; bu kampanyaların görsel metinleri fiziksel olarak aktif, çok boyutlu, otoriter, meydan okuyucu, cesur, komik, başarı odaklı ve durdurulamaz olma gibi çağdaş kadına ilişkin üretilen mitler aracılığıyla bağımsız ve güçlü bir kadın anlamını inşa ederken, söz konusu temsil pratikleri kadının güçlendirilmesi söylemini, kadınların bağımsızıklarının ve dişil güçlerinin bir işareti olarak önerilen markaları tüketmeye özendirilmesi aracılığıyla, ticari şirketlerin ileri tüketicilik hedeflerine ulaşmak için teşvik etmeye çabalamaktadır.

anahtar kelimeler: neoliberalizm, (popüler) postfeminizm, toplumsal cinsiyet ilişkileri, görsel temsil, kadın güçlendirme reklam kampanyaları 


\section{Introduction}

Since the media has been acknowledged as an important phenomenon which has become a main site in determining sexual "codes" and their "conduct" (McRobbie, 2004, p. 258) in cultural and social practices, women's representation in media's discursive strategies has long been criticized and being located the very heart of feminist media studies. Research in the early stage have revealed the significant role the media plays in the reproduction of traditional gendered roles and more particularly consolidation of social and cultural basis of sexualized identification of women in advertising, magazines, news, television series and so on. Thus, since the early stage studies have shown the media's side in gender representation through exploring how women have long been constructed and represented in the media in such a manner that patriarchal gender relations have been reproduced and consolidated, it has become an accepted criticism that the media is a key medium playing an important part in the production, construction and reconstruction, accommodation, regulation and disciplination of "sexual differences" (Zoonen, 1994, p. 66).

Acknowledging thesestudies'importanceand contribution to understanding the problematic representation of women in the media, more specifically in visual practices of advertising, over the last decade a newly emerging body of literature seems to suggest that there is a considerable changing trend in women's representation in advertising (Chen, 2013; Gill, 2007a, 2007b, 2008a, 2008b; Gill and Scharff, 2011; McRobbie, 1997, 2004, 2009; Zoonen, 1994). Despite considerable attention to women's traditional representation in advertising, little attention has been given to new era advertising depicting women in a liberalized and empowered manner by way of popularising and emptying meaning of some aspects of feminism. Contemporary media which is already characterised as postfeminist by Rosalind Gill (2007a), have begun to use the notion of freedom, girl power, choice and empowerment which means reflecting the beginning of a new era in representational strategies of the media about women. Some scholars have argued that the reason underlying this changing trend has been the changing capitalist interests that have necessitated re-interpretation of gender relations in line with the requirements of advanced capitalism. Following this point of view, other scholars have put forward a more specific claim which is based on the relational link between neoliberalism, postfeminist consumerism and gender relations (see Chen, 2013; Gill, 2007a, 2007b, 2008a, 2008b; Gill and Scharff, 2011; Kauppinen, 2013; Lazar, 2006).

Following Dove Real Beauty global advertising campaign launched in 2004, companies have begun to incorporate celebration of women's empowerment especially into their American and Western advertising practices and today a considerable number of women empowering advertising have been circulating in the media. Considering representation as the dominant means of social and cultural construction of reality, examination of produced meaning and uncovering 
the ideologies contemporary advertising visually carry, is important if we are to understand why contemporary media is evolving toward a postfeminist structure, what makes discourse of women's empowerment attractive for today's media, and more particularly what new ideologies are carried over women identities. This I did as I am concerned, in this research, with understanding how these campaigns' visual practices construct the meaning of newly empowered women and what ideologies are embodied in these representations.

\section{Theoretical Framework}

\section{The Construction of New Feminities and Postfeminist Subjectivities in Contemporary Media Culture}

Unlike the traditional knowledge produced about the representation of women in the media, feminist critique of the popular media images and women's cultural genres have pointed out that over the last decade we have been experiencing the representation of new versions of womanhood being constructed in commercial media texts (Chen, 2013; Gill, 2007a, 2008a, 2008b; Lazar, 2006; McRobbie, 2004, 2009; Toffoletti, 2014) and the point reached at present in women's media representation has shown that compared to previous periods there is a considerable change in women's media representation and, new media culture, particularly advertising, has intended to represent women in a liberalized manner using the empowerment rhetoric (Gill, 2007a, 2008a, 2008b; Gill and Scharff, 2011; McRobbie, 2004, 2009). From this perspective, turning our attention to the new era discussions on women's representation in the media, Rosalind Gill, who takes a critical approach to women's new representation in popular media images, has characterized the changing landscape in advertising as a noticeable change "from objectification to subjectification" (Gill, 2007a, p. 147), or in other words, from being represented "as passive objects of the male gaze" to being depicted "as active, independent and sexually powerful" (Gill, 2008a, p. 35). Following this trend, empowerment rhetoric, or as some scholars characterise it "Girl Power" (Chen, 2013, p. 44; Gonick, 2006, p. 2), and "power of femininity" (Lazar, 2006, p. 505) have started to be very clearly observed in contemporary advertising and starting from the 1990s construction of new form of femininity within the discourse of empowerment and depicting an assertive, independent and dynamic "new girl" (Gonick, 2006, p. 2) have become the common characteristic features of advertising addressing contemporary women by promoting some popular assumptions of feminism being used at the global level (see Chen, 2013; Gonick, 2006; Gill, 2008b; Gill and Scharff, 2011; Lazar, 2006).

From Gill's (2007b) perspective, which makes the popular media distinctive from previous periods is that feminism has been becoming one of the popular phenomenon of the media discourses, and women have started to be represented as active, independent, liberated and empowered individuals 
as distinct from their previous generations (Burkett and Hamilton, 2012). Thus, it can be claimed that some terms which remind us of feminism such as "empowerment, agency, self-actualization and promotion of women's success" have started to frequently appear in today's media discourses (Kauppinen, 2013, p. 135). In other explanation as Chen (2013, pp. 440-447) highlights over the last decades "choice, freedom and agency" which are "familiar feminist terms" have become the main notions of images depicting women who now have been given more self-confidence in terms of being integrated into heterosexual relations and postmodern consumer culture. In this sense, concerning how these changes constructing all women as empowered identities should be read, evokes questions and interpretations among scholars like "are they feminist icons of empowerment or is something more complicated going on?" (Gill, 2008a, p. 37); "have they incorporated or recuperated feminist ideas, emptying them of their radical force and selling them back to us as sanitized products or lifestyles to consume?" or could it be possible that the media is now should be considered as "postfeminist?" (Gill, 2007b, p. 41).

Scholars who have been searching for answers to these questions have suggested different interpretations. From Lazar's (2006, p. 505) perspective, although these terms can evoke some feminist values, they have been used not to circulate feminist ideologies but to promote postfeminist assumptions which establish the idea that struggles of women to reach full equality have been ended and today's women can "have it all" (Lazar, 2006, p. 505). In a similar vein, Kauppinen (2013); Lazar (2011); McRobbie (2004) claim that today's media culture appears to consider feminism by way of popularizing some feminist assumptions using the discourse of freedom and choice or getting into circulation stories and images of new women celebrating their advancement within the rhetoric of liberation, independence and power which have been linked to new femininities in order to promulgate the idea that feminism is no longer needed. McRobbie (2009, p. 130) has regarded this trend as postfeminism which refers to "a kind of anti-feminism" and Gill's (2008a, p. 39) argues that media and advertisers have attempted to include "the cultural power and energy of feminism while simultaneously neutralizing or domesticating the force of its social/political critique". Another criticism is that women can consider themselves as empowered on the individual basis; this has undermined developing collective feminist consciousness on women's social and cultural structural problems (Riordan, 2001).

Some critics also have suggested that increasing purchasing power and economic independence of women, which is supposed to be turned into a valuable resource for capitalism as a growing wealth of postmodern consumerism, have required the construction of a new version of femininities (see Macdonald, 1995; Zoonen, 1994). In addition to increasing economic power of women, reactions which arose in the 1990s against the images of idealized womanhood in the media have compelled advertisers to reconsider their 
strategies in favour of those which can simultaneously attract women's attention while assimilating criticism (Gill, 2008a). Thus, new trend representation have emerged as new marketing strategies targeting women who have economic independence and calling them to consume advertised products "as signs of their power and independence (from men)" (Gill, 2008a, p. 36). From Lazar's (2006, p. 505) perspective, since postfeminism has emerged as a "consumeroriented" advertising discourse, it has taken a crucial role in the assimilation of feminist criticisms of women's problematic representation. To do this advertisers have attempted to integrate some popular meanings of feminism distilling them from their actual social and political context and branding them in order to promote consumption (Lazar, 2006). In this sense, the new emerged media discourse of newly empowered women, in which women are positioned "in relation to the emerging configurations of subjectification" can be read as the manifestation of economic demands in response to capitalist practices and the reorientation of women's role in societies where women have started to show a significant socio-economic contribution to the global economy (Gornick, 2006, p. 1). In similar vein, Arthurs (2003, p. 87) has interpreted this changing trend emphasizing "postmodern consumer culture" which requires the exploration of new and expanded market values to maintain capitalist interest in response to changing capitalist purposes as a backdrop against which women's identities have been reconstructed putting a new form of commodification of self in relation to postfeminist assumptions into practice in popular media culture (Arthurs, 2003).

From some feminist critics' point of view, popularization of some feminist assumptions in advertising has been evaluated as proposing new critical terms such as commercialization or/and commodification of feminism, and feminist consumerism (see Gill, 2008b; Johnston and Taylor, 2008; Lazar, 2006; McRobbie, 2009; Riordan, 2001). For example, Johnston and Taylor (2008); Lazar (2006) and Riordan (2001) argue that articulation of some ideas of feminism in the discourse of girl power is feminist consumerism which means branding global discourse of popular feminism in order to promote consumption of commodities in the globalizing economy. All terms representing same ideological background have been explained as commercializing some of feminist ideas such as "liberation, freedom and independence" (Chen, 2013, p. 447) and selling them by way of attributing to advertised products in order to integrate much more women into consumer culture (Chen, 2013; Gill, 2008b; Lazar, 2006; McRobbie, 2009). So, commodification of feminism has operated on the understanding that encouraging women to internalise the idea that buying a suggested product will empower them (Gill, 2008a).

Considering advertising as a valuable part of a capitalist market, one important reason why advertising has changed throughout its history is that gender relations had to be reinterpreted in response to changing economic and social relations and observing historical changes in advertising culture can thus 
lead us to unpack ideologies embodied in changing approach in women's media representation (Gill, 2008a). One of the earliest example of articulation of popular feminist assumptions in advertising has been observed in Dove advertising campaign for Real Beauty aired in 2004, a campaign which depicted "women who were wrinkled, freckled, pregnant, had stretch marks, or might be seen as fat" (Johnston and Taylor, 2008, p. 942). In so doing, as a global feminine brand, Dove engaged in feminist critique of idealized female body in advertising. Some scholars, such as Murray (2012) and Johnston and Taylor (2008) have examined the campaign in the case of consumption of popular feminist assumptions in relation to global consumer culture.

Murray $(2012$, p. 1) have ended up observing that:

This postfeminist-supported campaign encourages the global spread of and individuals' enlistment in postfeminist citizenship via becoming a 'real beauty' who self-brands her neoliberal identity ideologically and materially in the name of empowerment.

Johnston and Taylor (2008, p. 961) on the other hand contend that:

While the Dove Campaign for Real Beauty provides a critique that partially disrupts the narrowness of Western contemporary beauty codes, it at the same time systematically reproduces and legitimizes the hegemony of beauty ideology in women's personal lives in the service of expanding sales and corporate growth.

They then go on to note that, Dove's strategic approach, which they have termed it as "feminist consumerism", stimulates women "to channel dissent and practice self-care by engaging with corporate marketing campaigns and purchasing beauty products" (Johnston and Taylor, 2008, pp. 961-962). The contradiction in this, observe Johnston and Taylor (2008, p. 962), lies in its "imperative to promote self-acceptance and at the same time increase sales by promoting women's consumption of products that encourage conformity to feminine beauty ideology". In this sense, it seems an accepted criticism in the existing literature that changing trends in women's representation in advertising, can be considered as a reinterpretation of social changes in response to changing capitalist interests and global consumer culture which not only requires capitalizing consumption of popular assumptions of feminism but also assimilating the feminist critiques of problematic representation of women in advertising in order to perpetuate the economic, social and political capitalist ideologies (Murray, 2012). 


\section{The Role of Neoliberalism in the Promotion of Postfeminist Assumptions}

Some scholars (such as Chen, 2013; Gornick, 2006; Gill, 2007a; Gill and Scharff, 2011; Kauppinen, 2013; McRobbie, 2009) have suggested that in an attempt to understand changing representational practices in popular media in order to answer the crucial question of how new form of femininities being constructed in popular media using girl power or "can-do" girl rhetoric can be linked to changing cultural, social, political and economic ideals, the relational link between neoliberalism, gender relations and postfeminism, which is still in the discovering process, needs to be considered together (Gill, 2008b, p. 442). This is crucial in unpacking ideologies embodied in the popular media images depicting women using empowerment rhetoric promoting postfeminist assumptions (Gill, 2008b). From Gill's (2008b) perspective what makes this relational assumption possible is that while there is no enough examination exploring this relationship in the existing literature, it is noticeable that neoliberalism and postfeminism share some critical ideological similarities and their relational operation can be explained at three distinctive levels. First, both ideologies are embedded in individual independence. What this means is that individuals should be free to think and act independently without any "pressures, constraints or influence from outside" (Gill, 2008b, p. 443). Second, the ideals of neoliberalism autonomy and self regulation - are similar to those of postfeminism which promote individual decision-making. Thus, postfeminism operates not only in responding to feminism but also in spreading neoliberal ideas. The third connection is that there is a trend in contemporary cultural practices that women are aimed at promoting a paradigm shift by being able to managing and disciplining themselves (Gill, 2008b). Both ideologies suggest that women spend all their energies on transformation of the self. These parallels between postfeminism and neoliberalism suggest that the presence of neoliberalism has greatly influenced the emergence of postfeminism (Gill, 2008b).

From a Foucauldian perspective, which has been applied as one of the key approaches to representation, power relations have been operated and reproduced through "discursive strategies and representational practices" (Hall, 1997; Martin, 1988, p. 9). McRobbie, who has suggested one of the earlier critique of changing trend in women's representation in women's magazines and advertising, has pointed out that women's magazines and advertising have had a crucial role in the process of producing gendered ideologies which take under guarantee the reproduction of the power relations in societies (McRobbie, 1997). In this sense, understanding "which female subjectivity now finds itself being constructed" (McRobbie,1997, p. 195) or what Gill (2008a, p. 35) has called "contemporary constructions of female sexual agency" in popular media culture 
can not be examined without taking into account the "contemporary operation of power" (2008a, p. 35) which embedded in representational practices. Over the last decades, the modern operation of neoliberal power has required the emergence of new gendered ideologies in order to respond to cultural and social changes and this has led to the social existence of women being reinterpreted to adapt them to contemporary neoliberalism and postmodern consumerism, a move which has necessitated the construction of new ideal women who are supposed to be free, independent and self-responsible individuals in terms of choosing marketed products (Gill, 2008b). What these scholars imply is that when considered new trend advertising images depicting women in empowered manner in the light of requirements of modern capitalist socio-economic operation and, in a narrow sense, circulation of neo-liberal values through postfeminist media discourses (Chen, 2013; Gill, 2007a, 2008b; Gill and Scharff, 2011; Kauppinen, 2013; McRobbie, 2009), it can be well understood that these representations have been depicting new women who have been representing "modernized neoliberal version of femininity" (Gill, 2008b, p. 441).

In this regard, changing approaches to women's representation in popular women's genres (Chen, 2013), in other word, representing women active, independent and empowered individuals can be well understood considering working process of modern neoliberal power that operates not through direct "external oppression" and domination but through "normative regulation" and "governmentality" which produce well regulated and empowered individuals (Gill, 2008a, pp. 40-46; Kauppinen, 2013). It is important to observe however that neoliberal power not only works by demanding that subjects live up to expectations of "advanced capitalism" that requires high level consumerism (Bartky, 1997, p. 107), but also by creating new individuals who are ready to respond this consumerism. As such, the re-construction of "feminine subjectivity" (Gill, 2008a, p. 35) within the rhetoric of freedom and choice in contemporary media culture can be evaluated as a way in which women have been reconstructed as new ideal subjects of neoliberal consumerism. In this sense, it is assumed that newly constructed female subjects who have been called celebration of "individual choice and freedom" (Chen, 2013, p. 440), as Gill describes (2008a, p. 36), in terms of "buying a range of empowering products", actually is the reflection of working "neoliberal process of subjectification" (Chen, 2013, p. 440). Empowered and liberated individuals have been required as a new obligation of contemporary era in order to reinterpret citizens in neoliberal sense while producing new and valuable markets. For this purpose, the meaning of femininities being constructed in contemporary media in line with neoliberal consumer ideology has begun to be based on "empowered, assertive, pleasure-seeking" and "have it all" (Chen, 2013, p. 441) individuals. 
Empowerment attributed to women in popular advertising cannot be considered as a real empowerment but is rather a new ideological discourse serving restructured changing capitalist values in line with neoliberal sense and replacing them into social and cultural practices by means of constructing women as active and free individuals fully responsible for themselves. New women being constructed in the neoliberal sense are supposed to be desiring to improve their choices and competitiveness redesigning themselves in line with the prescribed values and they are newly empowered women who have been given the right to deliberately enjoy their empowered beauty and new form of sexual objectification (Chen, 2013; Gill, 2008b; Lazar, 2011).

\section{Methodology}

This research intended to examine how new trend women empowering advertising campaigns depict women. To do this, this research aimed to look at the global women empowering advertising campaigns produced over the years 2014 and 2015 which represent one of the very current examples of women's media representation. In the selection of appropriate sample, I decided to sample three existing women empowering campaigns aired by global popular commercial companies in selected years. In the sampling process, I discovered four women empowering advertising campaigns conducted in 2014 which are CoverGirl: Girls Can, Pantene: NOT SORRY Shine Strong, ALWAYS: Like a Girl, Under Armour: I will what I want and one in 2015 which is Gillette Venus: Use Your And Ad Campaign; I then decided to sample three of them based on the number of videos belonging to the each campaign. In this manner ALWAYS: Like a Girl and CoverGirl: Girls Can Advertising Campaign conducted in 2014 and Gillette Venus: Use Your And Ad Campaign aired in 2015 were defined and selected for analysis.

Video commercials of the sampled campaigns as primary data of the research were collected in the online environment between the month of June, July and August 2015 primarily from the YouTube Channel that have been also placed as the third party link in the related pages of companies' websites as well as their owner Procter and Gamble, and creative agencies of the campaigns. From 21 advertising video belonging to the sampled campaigns and circulating on the mentioned Internet channels, one video for each campaign based on considering their initial video which are the most recognized and popular ones was selected for analysis. In the selection of particular research methods for the analysis of visual materials, this research considered social semiotic and critical discourse analysis in an attempt to develop an in-depth examination of following research questions: 
1. How have new trend approaches to women's representation in advertising constructed the meaning of new femininities?

2. What stereotypes and myths are being produced about contemporary women and which ideological meaning have these representations produced?

3. How have women empowerment been structured in relation to companies' economic and commercial values and how have these representations promoted them?

4. In a broad sense, to what extent can these representations explain to us how women identities have been reconstructed in relation to changing cultural, social and economic ideologies?

In order to answer research questions based on understanding produced meaning in visual practices of the advertising campaigns, representational, interactive and compositional meaning that are the main components of production of visual meaning (Jewitt and Oyama, 2001) (i.e. narrative and conceptual structures, distance, contact, salience, editing and information value) were examined through taking a multimodal approach to analysis of visual material in order to understand how these videos "visually, verbally, musically or sound-wise" (ledema, 2001, p. 191) construct the meaning of empowered women. In order to provide more detailed understanding on relational link between image and verbal text some examples from advertising videos' spoken language were analysed applying critical discourse analysis to arbitrarily chosen examples combining with visual analysis of videos.

\section{Analysing Advertising Campaigns' Video Commercials Using the Social Semiotic Framework and Categorical Findings}

Before moving to the in-depth, multimodal analysis of the video commercials which explore how the meaning of empowered women are constructed visually, verbally, musically and from audio sources, Table 1 presents some examples taken from these videos in order to show the basic signs represented in these visual materials. 
Table 1. Some visual and verbal signs that signify contemporary female power in the analysed video commercials

\begin{tabular}{|c|c|}
\hline Signifier & Signified \\
\hline Astronaut helmet & Science, space \\
\hline Pink ballerina dress, football ball & $\begin{array}{l}\text { Feminine, cute and pretty, masculine, sporty } \\
\text { and physically active }\end{array}$ \\
\hline Skateboard, graffiti & $\begin{array}{l}\text { Physically active, unordinary, courageous, } \\
\text { rebellious, free }\end{array}$ \\
\hline $\begin{array}{l}\text { Electronic drum, motorbike, black heavy } \\
\text { shoes, leather tights and leather coat }\end{array}$ & Darer, strong, masculine, rebel, unstoppable \\
\hline Electronic workshop & Smart, intelligent, talented \\
\hline $\begin{array}{l}\text { White patterned green polished nails, love, } \\
\text { an open book, library and bookcases, thick } \\
\text { rimmed glasses }\end{array}$ & $\begin{array}{l}\text { Well-groomed, romantic, intellectual, knowl- } \\
\text { edgeable, sophisticated }\end{array}$ \\
\hline $\begin{array}{l}\text { Sewing machine, wooden ground, silver and } \\
\text { shiny high heel shoes }\end{array}$ & Traditional/modern \\
\hline Short hair-suit & Masculine \\
\hline Ice hockey stick and pink polished nails & Courageous, daring, well-groomed/modern \\
\hline Hip-hop singer & $\begin{array}{l}\text { A highly dynamic dance, disobedience, rebel- } \\
\text { lion }\end{array}$ \\
\hline $\begin{array}{l}\text { Pink hair, teddy bear wearing leather coat, } \\
\text { weird facial expressions }\end{array}$ & $\begin{array}{l}\text { Free spirited, off the wall, cute, funny and } \\
\text { self-confident }\end{array}$ \\
\hline $\begin{array}{l}\text { Black leather coat, black leather bustier and } \\
\text { black leather beret }\end{array}$ & $\begin{array}{l}\text { Strong, courageous, sexual power, rebellious, } \\
\text { rocker }\end{array}$ \\
\hline Girls, pink, dark blue/blue & Female sex, femininity, masculinity \\
\hline $\begin{array}{l}\text { Rock, check, rap } \\
\text { Running, fighting, throwing, hitting, kicking, } \\
\text { swimming, shooting, scoring, walking, baseball } \\
\text { bat, kick box }\end{array}$ & $\begin{array}{l}\text { Rebellious, aggressive, rule breaker, darer } \\
\text { Physically strong and active, challenger, physi- } \\
\text { cal confident, masculine }\end{array}$ \\
\hline
\end{tabular}

\section{Physical Agency: Physically Stronger and Athletic Women}

Always Like A Girl campaign video commercial is conceptualized to give a positive meaning to the phrase "like a girl" to the viewer mainly by showing teenage boys and girls, young men and women. The video begins by showing a young woman framed from behind and filmed in long shot. By this distance 
framing the audience is made to recognize the set as a film shooting studio by including a camera and cameraman symbolizing the filming process within the frame. In the scene one sees a man approaching the woman by holding a cinema clapper. Following this shot, the viewer is shown the same woman from frontal angle and in medium shot with the woman and a man's hand holding the cinema clapper in front of her face appearing together in the frame. While her gaze looks directly at the viewer, the man withdraws the cinema clapper which means shooting has begun. To this point, there is no any background sound. When the man closes the cinema clapper, the sound heard through this action breaks the silence. Such a beginning encourages the viewer to develop emotional responses as it arouses excitement and interest and creates a sense of realism about what is going to be presented (Always, 2014, 0:00-0:03). Later on the linguistic message which is "What does it mean to do something like a girl?" appears as placed in the centre (Always, 2014, 0:04). The linguistic signs are designed by combining blue and white colour against a dark blue background. The phrase "like a girl" is emphasized and separated from the overall message by being presented in white and within quotation marks. On the other hand, there is a strong connection between the linguistic message, and the brand achieved by using dark blue, blue and white; the viewer is already familiar with this colour combination from the products and logo of the brand.

Along with the displaying of the linguistic message, the viewer also begins to hear the voice of a female director again seeing the same young woman from frontal angle in full shot of her body. There is nothing in the background and the viewer is addressed by using the same dark blue in the background. The director begins to talk by giving the woman an action command asking her to show "how it looks like to run like a girl". Following this, we see another young woman, a man and a boy performing the same action in the same studio. All represented participants run slowly and feebly by waving their hands or representing how women worry about making their hair messy thereby representing a feminine code of behaviour in order to emphasize their understanding on the phrase "like a girl". In similar vein, the video goes on to present the same women, man and boy as they are asked to fight and throw like a girl to which they make the same feeble gestures as they continue to show overly stereotyped feminine behaviours (Always, 2014, 0:06-0:38). These characters usually appear alone in the shots and there is no interaction between them. On the other hand, they are usually framed from frontal angle and the viewer looks at the screen from their point of view. The viewer sees them as framed full and medium shot. While the viewer's attention is called to the physical action done through the full shot of them, the medium shot is used to establish more interactive relation with the viewer. All this occurs in the same studio as the same scene consisting of series of interrelated shots.

Later on in the video, several young girls, around ten years old, are brought into the same studio and asked to role running and throwing like a girl through 
the same instructions given by the same director. Contrary to the young women and men depicted as showing stereotyped feminine behaviours, girls role to run, throw and fight as hard and as fast as they possibly can. A very young girl dressed in pink clothes is asked to describe the meaning of run like a girl and she describes the phrase, making eye contact with the viewer, as "run as fast as you can" (Always, 2014, 0:42-1:03). The choice of verbs, run, throw, fight denotes high levels of physically active actions and body confidence, and in relation to the chosen particular phrase "like a girl" and dominance of blue tones within the context of gender relation between men and women construct the meaning of empowered women who have potential to act like men.

After this, the viewer is communicated to through another linguistic message asking "when did doing something like a girl become an insult" (Always, 2014, 1:05). The same dark blue background is maintained with the linguistic signs designed in the same blue and white colour in a manner which separates the campaign's slogan "like a girl". After a while we see another linguistic message "a girl's confidence plummets during puberty" which is followed by another linguistic message telling "Always wants to change it" (Always, 2014, 1:25-1:31). Up to this point, while the viewer has been addressed using the same colour combination connoting the brand rather than using the brand name directly, now the viewer is allowed to see brand name. The linguistic sign representing the brand name is designed to be separate from the other linguistic signs by using handwriting style in white colour symbolizing the same style being used in the brand emblem, and in the language the name of the brand is structured as the subject of women's empowerment who is willing to influence girl's confidence positively.

After displaying the linguistic message, more particularly emphasizing the brand name, the same young women are brought in front of the camera, and they are represented as having realized their misunderstanding of the phrase and asked for advice they can give young girls to stay confident. They then perform how they can run like a girl differently. We see the same young women and girls acting in a strong and athletic way (Always, 2014, 2:12-2:20). While they are represented in this way, the audience is called to show an emotional response by turning up the volume and tempo of background music while coming to the end. Then, the video ends by showing a young woman running strongly toward the camera while looking at the viewer's eyes (Always, 2014, 3:02). After this strong interaction, the video is ended by presenting the brand emblem designed to cover the frame. This is accompanied by another linguistic message which reads "rewrite the rules", and the connection between brand name and linguistic message is achieved by using the same colour and the same handwriting style (Always, 2014, 3:15).

In this regard, while in this case the relationship between visual images and linguistic text construct the meaning of empowered women as physically 
active and having physical potential to make actions as much as men can, the ideological position embedded in this representational practice manifests itself at several levels. The initial point is that the brand, which is marketing feminine products using the rhetoric feel confident in their general marketing practices, makes an endeavour to identify empowered women as physically active by promoting the discourse of women's confidence in relation to the represented physical actions which require physical confidence and comfort. This promotes an imaginary relation between women's physical capacities to make actions and brand value. The second point which makes this reading even more critical is that the brand positions itself as the subject of women's empowerment and power of rewriting rules of femininity. This implies that while the video is visually constructing the meaning of empowered women who are physically active, the brand is ideologically positioned to the configuration of physically active, strong and confident women.

\section{All in One: Identification of Contemporary Women as Unique, Multidimensional and Many-sided}

In Gillette Venus Use Your 'And' campaign's video commercial we mainly see a middle aged woman speaker talking throughout the whole video. This enables the viewer to recognize her as the main actor among represented women in the video. The video also includes a young girl and several young women depicted in different environments and different roles. The video is launched by showing a little girl wearing an astronaut cap with a pink ballerina dress running and playing soccer. As the scene goes on, the viewer is addressed by the spokeswoman framed close up from frontal angle and she establishes an interactive relationship with the viewer through her gaze. In the background, music representative of the brand's general song (She's Got It) rewritten within the content of the advertising campaign is played.

As she begins to talk to the audience she says; "They told you, you could be anything. A beautiful astronaut. A soccer-player ballerina. A superstar. Then said here is what you really are" (Gillette Venus, 2015, 0:01-0:16). She verbally addresses to the audiences distinguishing them as an individual using the second person pronoun "you" which calls the viewer to establish a strong personal interaction and "invite the viewer to come closer" (Kress and van Leeuwen, 2006, p. 118). Also claiming her potential is overlooked by "them" makes even more stronger this individualized distinction. The chosen particular words which are semantically opposed to each other (astronaut, soccer-player ballerina and superstar) in relation to the visual text is all constructing the meaning of many sided contemporary women. It is also important to note that in the scene which presents the little girl and the woman speaker, thirteen seconds in the video, the longest shot, presents the frame of the legs of the girl only (Gillette Venus, 2015, 0:03-0:06). 
Following scenes continue by showing a young Asian woman, with a unique style of clothes, going through book shelves in a library. Then, the viewer is shown another woman wearing a skirt about whom the viewer is only shown her legs and microphone boom pole implying that she is singing (Gillette Venus, 2015, 0:13-0:15). Following this scene, the viewer sees a medium shot of another young woman framed from behind. Then the viewer is shown a full shot of the woman speaker. The relational link between the young woman and woman speaker is achieved by maintaining the same place which is a white coloured room. The woman speaker is wearing a white t-shirt, a dark blue mini short and cream-colored high heels. The space she occupies is a large cream and white room and the dark blue represented in her short makes high contrast. The scene ends by directly showing a close-up framing of her legs (Gillette Venus, 2015, 0:16-0:19). Following this depiction the viewer is communicated by increasing the sound and tempo of the music and showing another young woman holding a skateboard and interacting with the viewer through her gaze (0:20). Later on, the viewer sees scenes depicting several women while playing drums, dancing, singing, riding motorbikes and wearing completely black leather clothes, skateboarding, playing the saxophone, playing volleyball, standing hands up, and also sees a couple holding hands and a young woman repairing an electronic instrument (Gillette Venus, 2015, 0:21-0:38). The scenes develop dynamically because we see the characters as actively doing something in relation to the woman speaker who speaks very dynamically by using her voice very actively in tune with the high tempo music going on in the background. The women are usually represented alone, on the other hand, crosscutting editing which means one character is positioned in relation to one another is mainly used (Gillette Venus, 2015, 0:31-0:32).

In relation to what is visually represented the woman speaker verbally continues to target women as individuals and calls them to celebrate their many sides by advising them that:

When someone labels you this or that, use your 'And' to take a stand. With your legs and your voice and your head and your heart. If someone says you are smart, say 'yes and'... If someone says you are pretty, say 'yes and'... Help them understand (Gillette Venus, 2015, 0:27-0:44).

Then the viewer is shown a full shot of the young woman who is dancing as beginning we are only allowed to see a close up frame of her legs. While the language used here includes mix of discourse of stereotypical femininity and empowerment through chosen particular words smart and pretty, the meaning constructed in relation to the visual texts produces the myth of empowered women who can be both intelligent and pretty. This reading is strengthened visually and verbally by following scene depicting the same young woman previously represented in the library. Initially the viewer is addressed by showing her hand searching for a book; then we see a close-up framing of her hand 
holding an open book. A very small part of the book is displayed. Her hand is framed from frontal angle by being placed in the centre. We see her polished green nails with the nail polish designed to write "love" in white. The letter L and $V$ represented on her nail polish are designed by associating the ' $\&$ ' symbol used in the brand's slogan and the campaign. The background and the book is blurred to make the linguistic signs the most salient elements of the frame. The woman speaker says "you are polished nails and polished mind" and then we see her while reading the book (Gillette Venus, 2015, 0:44-0:47). The feminine myth produced visually and verbally is that of a young intellectual woman who can keep her nail-polish desire as well as celebrating her sophisticated side.

Later on, the video visually produces similar meaning by depicting another woman shown following the close-up frame of the spokeswoman's legs. The woman is represented in a similar room to the one in which the speaker is represented, with a sewing machine and mainly pink tulle fabric around. Then the viewer is addressed by showing her lower legs and feet while she is sewing on the machine. We also see wooden material used in the design of the floor and, together with the sewing machine, they give a sense of tradition. In contrast to this depiction, she wears flashy high heels and red nail polish signifying a well groomed modern woman (Gillette Venus, 2015, 0:50). Following this, again we see the crosscutting editing used in order to relate the woman who is sewing to another woman who is playing drums. The scene begins with showing close up frame of a woman's legs and bottom of the drums and, through editing, the viewer is called to establish similarities by emphasizing similar action done by the woman's feet on the pedal of sewing machine and drums. Furthermore, the colour combination of light and similar tones in both images separates the woman's legs from the background and other elements of the frame (Gillette Venus, 2015, 0:50-0:51).

The video ends by showing a big ' $\&$ ' sign in blue organized in the middle. Then a linguistic message in white appears proclaiming "one dimensional labels limit your potential. Venus [separated from other linguistic signs by using the general brand logo] invites women everywhere to \#UseYourAnd to take a stand against labels" (Gillette Venus, 2015, 1:01-1:10). In the beginning while the viewer is called to recognize the brand using the white and blue colour connoting the brand, at the end the viewer is directly shown the brand name semantically placed as the subject of women empowerment. At the same time the brand's song telling "I'm your Venus, I'm your fire, your desire" (Gillette Venus, 2015, $1: 00)$ starts to be heard from the background. Finally, the brand's logo and the slogan "great legs" are shown in the end. While the visual strategies and linguistic elements used in the second linguistic message produce and affirm the brand as the basis of empowered women, the discourse produced in the background is structured in order to produce metaphoric meaning evoking and reproducing the brand's name and more particularly the brand's value in relation to empowered women. Particularly, the words "fire" and "desire" verbally 
articulate the meaning of empowered women who desire smooth legs while celebrating their many sides.

To this point what we visually and verbally read is that the notion of contemporary women which promotes the idea that women have a lot of potential and are many sided. On the other hand, while the video promotes the multidimensional identification of newly empowered women, it makes an endeavour to relate women's smooth legs by showing nine times close-up framing presenting only women's legs. The way the video ends enforces our claim as in the end the viewer is visually and musically communicated to by relating empowered women to brand's values. Overall in the Gilllette Venus video commercial promoted based on reducing labels against women evoking one of the common sense of feminism empowered women is structured and represented in a commercialised manner aiming to increase the brand value and empowered women are represented in the manner associating them to smooth legs as a value of sophisticated and many sided women which negotiates feminine beauty ideal in postfeminist sense.

\section{Rule Breakers and Rule Makers}

In the CoverGirl Girls Can campaign's video commercial featuring popular rock and pop singer, rapper, comedian and model, the viewer is addressed mainly showing seven women. These women appear alone in shots and the viewer sees them as framed from frontal angle which increases interaction and participation between represented participant and the viewer (Jewitt and Oyama, 2001). We usually see them in close-up and medium shot and each woman looks directly into the viewer's eye and speaks directly to the audiences focusing their gaze on them. In other words their gaze are positioned at the same level with the audience which means we look at the video from their "point of view" (Jewitt and Oyama, 2001, p. 147). Through this, instead of interacting among represented participants, they establish a strong relationship with the viewer. An analysis of how these characters are positioned in relation to each other shows continuity of the same colour combination (hot pink, white and black), similar facial expressions and gestures; similar discourses linguistically and semantically produced by women also establishes relational ties among represented women. Again we see a highly dynamic video because of the actively ongoing speech of represented participants, physical action of them, linguistic messages sometimes appear in the screen and melodic background music accompanying them during the video. Furthermore, the combination of hot pink, white and black flashing in the background in relation to rapid transition from one shot to another gives a sense of dynamism. Similar to the other videos, the Girls Can video is also structured to create a high interactive sense among audiences and represented women characters; the viewer is therefore called to establish a personal relationship with the identities of the represented women which symbolizes fun, assertive, strong and defiant women. 
The video launches with the speech of comedian Ellen DeGeneres who ironically says "girls can't" by focusing her gaze to the viewer. From Gill's perspective using ironically structured language which is a popular phenomenon in women empowering advertising is used in order to call "audiences as knowing and sophisticated consumers" (2007a, p. 159). Then the viewer is shown the linguistic sign "can't" in a combined white and pink colour. Following this, the video continues showing Pink with a cinema clapboard in front of her as we see the linguistic message "CoverGirl" and repetition of pink and white in the film clapboard. Then we see the model very closely as we see another woman holding a hockey stick; she shows her index finger which is polished in the same pink colour. Following her we see another young woman in different frames; she wears a hip hop cap, and we see the same colours white, black and pink blinking in the background. Then the viewer is shown a middle aged rocker looking at the viewer and wearing a black leather coat and spotting black nail polish. Her expression and gesture connotes assertiveness. Along with this scene women take up the speech as they go on saying "Girls can not rock. Girls can not be strong. Girls can not check. Girls can not be funny. Girls can not rap. Girls can not run the show. Girls can not dance crazy. Girls can not..." (Covergirl, 2014, 0:00-0:22).

During their depiction we see Katy Perry, who also wears a black dress, black leather hat, leather wristband and her nails also polished black. Then, she is placed against a completely white background turning pink. When the background is turned into white her pink toned make-up becomes clearer. Her expression is serious and her gesture, in relation to the her clothes, as she ironically says "girls can not be strong" and puts her arms up metaphorically represent her power and produce the meaning of an assertive and defiant woman (Covergirl, 2014, 0:08-0:09). This depiction goes on showing ice hockey player, comedian, young rapper, model, middle-aged rocker, and American rock singer Monae dancing. During their depiction, the viewer is addressed keeping the same narrative and conceptual structures and interactive relation produced through their gaze and the viewer's position to them. In here the particular chosen words which are rock, strong, funny, rap, crazy in relation to the what is visually represented evoke women who are rebel, darer, challenger and rule breaker (Covergirl, 2014, 0:10-0:22).

Then the video goes on addressing the audience changing the conversation from "girls can't" to "girls can" by positioning the middle-aged rocker close to the viewer. Then we see the ice hockey player explain her success with determined facial expression how she achieved while everyone claimed "you can not". As Lazar (2006, p. 510) mentions self-determination "which constitute an important goal for feminists and postfeminists alike, albeit envisaged differently" is popularised in contemporary advertising in order to construct the meaning of feminine power. Unlike the feminist discourse of self-determination which means collective consciousness for women's right to act in their life 
choices, in advertising popularizing feminist terms, the term is constructed from individualized perspective (Lazar, 2006) as structured in the campaign's visual and verbal practices targeting women as "you" and representing main character alone while celebrating her individual success obtained through self-determination. Then, we see the pink, white and black combination and linguistic sign turned into "girls" pronounced in lower cases and "can" pronounced in upper cases. Then the viewer is allowed to see her pink tones make up in relation to her ice hockey helmet by showing close up framing of her. Following this we see her in medium frame wearing an ice hockey outfit and holding an ice hockey stick and again directly looking at the viewer. The linguistic message "be courageous" is produced not only verbally but also visually in pink (Covergirl, 2014, 0:24-0:30). Then we again see Pink depicted as holding a small white teddy bear wearing a leather coat and its pink hair evoking the represented woman's hair colour and design. She looks at the teddy bear by making a funny face. In similar manner she is also depicted against the pink, white and black flashing background. Then we see her wearing a leather skirt while making crazy movements with her microphone and the linguistic message saying "challenge" is produced in the same colour combination and manner (Covergirl, 2014, 0:32-0:36).

Colours, like other semiotic resources, symbolize another semiotic mode which is operational in order to convey culturally located meanings to the signs (Kress and van Leeuwen, 2002). We know that the pink and white colour have long been used in women's magazines and advertising in order to make a connection to women's sexual identities by producing the meaning of pureness, prettiness and loveliness. As Koller (2008, p. 418) mentions the pink colour can be considered "as an example of a semiotic resource that draws on complex discourses and mental models of femininity to both reproduce and challenge gender ideology". In addition to the traditional use of pink in women magazines and advertising images, she investigated that pink has begun to be associated with "fun, independence and confidence", and new visual practices of pink represent "a post-feminist colour indexing economically independent, hedonistic femininity" (Koller, 2008, p. 418). The use of black colour and leather by women has also been considered culturally and socially as symbolizing independent, free, strong and cool women with black sometimes associated with feminism. While the representational meaning produced in this example promotes empowered women as assertive, daring and challenging, pink symbolises a new form of feminine identities who are funny, strong, challenger and celebrating dancing like crazy is produced again by renegotiating the association of pink to femininity. It is a strengthening idea that the pink colour now finds itself being used in order to promote construction of contemporary meaning of girlhood promoting postfeminist feminine identity.

Up to the end the video shows the same women as they address the audience saying "Come on COVERGIRL's! Rap, be funny, be off-the-wall, rock, be strong, run the show, make the world a little more easy, breezy, and beautiful" 
(Covergirl, 2014, 0:49-0:58). The discourse produced in the end is structured in the way that the word girls which is used until here is changed to COVERGIRL's, and the audience is verbally addressed using the brand name and places women metaphorically into brand. In the end, reproducing the brand slogan which is "easy, breezy, and beautiful" conveys an ideological position which is embedded in this representational practice. In this manner women are called to establish an imaginary relationship between the brand and their potential feminine power. Seeing the end showing the brand name in pink also supports this reading because the linguistic sign visually places and reproduces the cosmetic brand itself as the main basis of the empowered women. It is also worthy of note that although represented women are mainly middle aged, the campaign's discourse is structured in the manner popularizing the word girl, like in Always advertising campaign, which may undermine feminist critique of the word as considered sexist.

\section{Final Debate and Conclusion}

Through this small-scale research, just as espoused in the emerging literature, we are able to recognize that unlike the traditional representation of women in the media which has seen women depicted as passive and dependent, contemporary advertising trends tend to portray women as physically active and athletic, success-oriented, sophisticated, unstoppable and so on. However, as scholars of women empowerment in advertising claim, these campaigns' visual and discursive strategies make an endeavour to promote brand's commercial values in relation to the empowered women. Consequently, this allows us to argue that the empowered women being constructed in new era advertising is an ideological discourse serving brand's economic and commercial values and being promoted as brands' female consumer-oriented marketing strategies. In each campaign's representational practices, the related brand is positioned as the fundamental subject of empowered women, and this ideological position is strengthened through promoting brand's products as a sign of feminine power. From this regard, in a broad sense what these representational practices tell us is that gender relation, more particularly women identities, have had to be reconstructed in response to changing economic ideals which have required a recharacterisation of women as empowered individuals who are ready to respond to neoliberal consumerism which integrates women's economic power into new economic expectations by way of popularising postfeminist discourse of feminine power. Then, the new femininities being constructed in contemporary advertising can broadly be read as a construction of contemporary female consumer identity which is inextricably linked to advanced capitalism.

This analysis can be meaningful in order to discover newly emerging problematic issues in women's representation in advertising and changing capitalist ideologies carried over gender relations more particularly women identities. While this research can be a good starting point to discover the manner 
in which women are represented in women empowering advertising campaigns as it points to the ideological values carried over women's representation in contemporary advertising; in an attempt to take a wider perspective, considering the audience response to and interpretation of women empowering advertising visuals and discourses can also provide an important platform for understanding how viewers perceive, understand and consume deliberately produced meanings in empowered women images. In this study looking at the audience response was not possible because of time limitation, but this can contribute to unearth which myths and stereotypes produced in the images are promoted from the audience's perspectives. Accordingly, future research needs to focus on circulating discourses produced by audiences in the social media as well as images of forthcoming women empowering campaigns.

\section{References}

Always. (2014, June 26). Always \#LikeAGirl [Video file]. Retrieved from https:// www.youtube.com/watch?v=XjJOBjWYDTs\&feature=youtu.be.

Arthurs, J. (2003). Sex and the City and Consumer Culture: Remediating Postfeminist Drama. Feminist Media Studies, 3(1), 83-98. Doi: 10.1080/1468077032000080149

Bartky, S. L. (1997). Foucault, Femininity, and the Modernization of Patriarchal Power. In D. T. Meyers (Ed.), Feminist Social Thought: A Reader (92-111). New York: Routledge.

Berger, A. A. (2008). Seeing is Believing: An Introduction to Visual Communication ( $3^{\text {rd }}$ ed.). New York: McGraw Hill Education.

Burkett, M. \& Hamilton, K. (2012). Postfeminist sexual agency: Young women's negotiations of sexual consent. Sexualities, 15(7), 815-833. Doi: $10.1177 / 1363460712454076$

Chen, E. (2013). Neoliberalism and popular women's culture: Rethinking choice, freedom and agency. European Journal of Cultural Studies, 16(4), 440-452. Doi: $10.1177 / 1367549413484297$

CoverGirl. (2014, February 21). \#GirlsCan: Women Empowerment [Video file]. Retrieved from https://www.youtube.com/watch? $v=K m m G C l Z b 8 M g \& i n d e x=3$ \&list=PL1_vRQKoHSnxQmxjx03aOY6P-iYIW7DYv.

Gill, R. (2007a). Postfeminist Media Culture: Elements of Sensibility. Cultural Studies, 10(2), 147-166. Doi: 10.1177/1367549407075898

Gill, R. (2007b). Gender and the Media. Cambridge: Polity.

Gill, R. (2008a). Empowerment/Sexism: Figuring Female Sexual Agency in Contemporary Advertising. Feminism \& Psychology, 18(1), 35-60. Doi: $10.1177 / 0959353507084950$ 
Gill, R. (2008b). Culture and Subjectivity in Neoliberal and Postfeminist Times. Subjectivity, 25(1), 432-445. Retrieved 2015, March 27, from http://www. palgrave-journals.com/sub/journal/v25/n1/pdf/sub200828a.pdf.

Gill, R. \& Scharff, C. (Eds.). (2011). New Femininities: Postfeminism, Neoliberalism and Subjectivity. Basingstoke: Palgrave Macmillan.

Gillette Venus. (2015, January 6). Gillette Venus \#UseYourAnd [Video file]. Retrieved from https://www.youtube.com/watch?v=VFEaj2rNknU.

Gonick, M. (2006). Between "Girl Power" and "Reviving Ophelia": Constituting the Neoliberal Girl Subject. NWSA Journal, 18(2), 1-23. Retrieved 2015, January 31, from http://www.jstor.org/discover/10.2307/4317205? uid=28262 \&uid $=3738032 \&$ uid $=2 \&$ uid $=3 \&$ uid $=5910784 \&$ uid $=67 \&$ uid $=28260 \&$ uid $=62 \&$ s id $=21105290356371$.

Hall, S. (Ed.), (1997). Representation, Cultural Representation and Signifying Practices. London: Sage Publications.

ledema, R. (2001). Analysing film and television: a social semiotic account of hospital: An unhealthy business. In T. van Leeuwen \& C. Jewitt (Eds.), Handbook of Visual Analysis (183-204). London: SAGE.

Jewitt, C., \& Oyama, R. (2001). Visual Meaning: a social semiotic approach. In T. van Leeuwen \& C. Jewitt (Eds.), Handbook of Visual Analysis (134-156). London: SAGE.

Johnstone, J. \& Taylor, J. (2008). Feminist Consumerism and Fat Activists: A Comparative Study of Grassroots Activism and the Dove Real Beauty Campaign. Journal of Women in Culture and Society, 33(4), 941-966. Retrieved 2015, 3 February, from http://earbirding.com/3020summer2011/wp-content/ uploads/2011/07/Feminist-Studies-and-Dove.pdf.

Kauppinen, K. (2013). Full power despite stresses: A discourse analytical examination of the interconnectedness of postfeminism and neoliberalism in the domain of work in an international women's magazine. Discourse \& Communication, 7(2), 133-151. Doi: 10.1177/1750481313476596

Koller, V. (2008). Not just a colour: pink as a gender and sexuality marker in visual communication. Visual communication, 7(4), 343-368. Doi: $10.1177 / 1470357208096209$

Kress, G. \& van Leeuwen, T. (2002). Colour as a semiotic mode: notes for a grammar of colour. Visual Communication, 1(3), 395-423. Doi: $10.1177 / 147035720200100306$

Kress, G. \& van Leeuwen, T. (2006). Reading Images, the Grammar of Visual Design ( $2^{\text {nd }}$ ed.). London: Routledge. 
Lazar, M. M. (2007). Discover the Power of Femininity! Analyzing global "power femininity" in local advertising. Feminist Media Studies, 6(4), 505-517. doi: 10.1080/14680770600990002

Lazar, M. M. (2011). The Right to Be Beautiful: Postfeminist Identity and Consumer Beauty Advertising. In R. Gill \& C. Scharff (Eds.), New Femininities: Postfeminism, Neoliberalism and Subjectivity (37-51). Basingstoke, GB: Palgrave Macmillan.

Martin, B. (1988). Feminism, Criticism and Foucault. In I. Diamond \& L. Quinby (Eds.), Feminism and Foucault: Reflections on Resistance (3-9). Boston: Northeastern University Press.

Macdonald, M. (1995). Representing Women: Myths of femininity in the popular media. London: Arnold.

McRobbie, A. (1997). More! New sexualities in girls' and women's magazines. In A. McRobbie (Ed.), Back to Reality?: Social Experiences and Cultural Studies (190-209). Manchester: Manchester University Press.

McRobbie, A. (2004). Post feminism and popular culture. Feminist Media Studies, 4(3), 255-264. Doi: 10.1080/1468077042000309937

McRobbie, A. (2009). The aftermath of feminism: Gender, Culture and Social Change. London: Sage.

Murray, D. P. (2012). Branding "Real" Social Change in Dove's Campaign For Real Beauty. Feminist Media Studies, 13(1), 83-101. Doi: 10.1080/14680777.2011.647963

Riordan, E. (2001). Commodified Agents and Empowered Girls: Consuming and Producing Feminism. Journal of Communication Inquiry, 25(3), 279-297. Doi: $10.1177 / 0196859901025003006$

Zoonen, V. L. (1994). Feminist Media Studies. London: Sage Publication. 